\title{
PEMANFAATAN BAHAN AJAR BIOLOGI BERBASIS INTERNET PADA MATERI PEMBELAHAN SEL UNTUK MENIGKATKAN PEMAHAMAN KONSEP, MENUMBUHKAN LITERASI DIGITAL DAN KEMANDIRIAN BELAJAR
}

\author{
Riswanto \\ SMA Negeri 3 Rantau Utara, JIn. WR. Supratman, Rantauprapat, Kab. Labuhanbatu, Sumut. \\ E-mail: risonetwo@gmail.com
}

Diterima November 2018 dan Disetujui Desember 2018

\begin{abstract}
Abstrak
Demografi pengguna internet di Indonesia didominasi oleh generasi muda, dimana sebanyak 35,6 juta atau $26,9 \%$ dari total 132,7 juta pengguna internet di Indonesia berusia 10 hingga 24 tahun (APJII, 2016). Literasi digital bermakna kemampuan berhubungan dengan informasi hipertekstual, dalam arti membaca non-sekuensial berbasis sistem komputer atau platform digital (Davis \& Shaw, 2011). Dengan demikian, kemampuan membaca, memahami dan analisa berbagai sumber digital sangat penting. Mengingat proses belajar yang dilakukan di sekolah memiliki keterbatasan waktu, maka kemandirian belajar dipandang sebagai suatu hal yang mutlak harus dilakukan oleh peserta didik. Kemandirian belajar peserta didik ini perlu dikembangkan, ditingkatkan dan dibiasakan serta dilatih kepada setiap peserta didik. Karakteristik obyek Pembelahan Sel sulit untuk bisa ditemukan atau dihadirkan secara nyata pada peserta didik, sehingga untuk mempelajari proses Pembelahan Sel, selama ini guru lebih banyak menggunakan media gambar, charta atau model. Namun pemanfaatan media ini pun belum cukup membantu proses pembelajaran. Salah satu upaya pengembangan itu dapat ditempuh dengan memanfaatkan internet. Namun selama ini pemanfaatan itu masih belum optimal disebabkan keterampilan sebagian besar guru yang masih terbatas untuk mengakses internet. Internet menyediakan banyak media-media pembelajaran yang bisa diakses dengan mudah. Media-media itu dibuat menggunakan program multimedia berbasis computer seperti Macromedia Flash sehingga menghasilkan media animasi yang sangat menarik dan interaktif. Media-media animasi tentang Pembelahan Sel pun sudah banyak dan bisa ditemukan serta diunduh dengan mudah. Salah satu kelebihan media ini adalah adanya animasi yang memberikan gambaran lebih nyata tentang proses Pembelahan Sel sehingga peserta didik dapat dengan mudah mengamati gejala tersebut, dibanding media gambar atau charta. Untuk mengembangkan bahan ajar dengan memanfaatkan media animasi berbasis internet ini, yang perlu dilakukan guru adalah: 1). mencari situs-situs animasi pembelahan sel, 2). mengunduh dan menyimpan media animasi yang telah diperoleh, 3). membuat perangkat pembelajaranlain seperti LKPD atau modul untuk melengkapi media animasi tersebut menjadi bahan ajar. Pemanfaatan bahan ajar untuk materi Pembelahan Sel ini mampu meningkatkankualitas pembelajaran biologi, pemahaman konsep, menumbuhkan budaya literasi digital, motivasi dan kemandirian belajar.
\end{abstract}

Kata kunci: bahan ajar biologi, internet, Pembelahan Sel

\section{PENDAHULUAN}

\section{Latar Belakang}

Teknologi internet hadir pada masa ini sebagai media yang multifungsi. Dengan adanya internet, guru bisa memberikan kesempatan kepada peserta didik untuk memperkaya wawasan dirinya sendiri. Peserta didik akan dipacu untuk lebih memiliki inisiatif di dalam mencari berbagai ilmu pengetahuan. Demografi pengguna internet di Indonesia didominasi oleh generasi muda, dimana sebanyak 35,6 juta 
atau $26,9 \%$ dari total 132,7 juta pengguna internet di Indonesia berusia 10 hingga 24 tahun (APJII, 2016). Sementara itu, ada kesenjangan antara pendidikan literasi di Indonesia dengan kemudahan mengakses internet dimana penetrasi penggunaan internet di demografi berusia 10-24 tahun mencapai tingkat $75 \%$. Sementara itu belum ada pendidikan literasi digital yang terstruktur dan merata di Indonesia

Menyiapkan anak agar siap menghadapi era revolusi industri, tidak cukup sekedar pengadaan tablet atau pengadaan komputer di sekolah. Karena yang lebih penting yaitu penguatan literasi digital kepada peserta didik. Seta, A. K (2018) mengatakan, literasi digital yang dibutuhkan peserta didik yaitu human skill. Yaitu bagaimana adab peserta didik dalam menggunakan media sosial, mengasah critical thinking anak, emotional inteligent, social inteligent serta menanamkan nilai-nilai (value). Sehingga dalam praktek mata pelajaran sebaiknya satu komputer digunakan oleh tiga sampai lima anak misalnya. Sehingga anak dididik untuk bersosialisasi dan juga mengasah team work.

Laporan riset Programe for International Student Assesment (PISA) mengungkap, betapa tradisi literasi masyarakat Indonesia pada tahun 2012 ada di rangking 64 dari 65 negara yang diteliti. Sementara, indeks membaca dari peserta didik di berbagai negara yang diteliti, posisi Indonesia menempati urutan ke-57 dari 65 negara. Literasi digital bermakna kemampuan berhubungan dengan informasi hipertekstual, dalam artian membaca nonsekuensial berbasis sistem komputer atau platform digital (Davis \& Shaw, 2011). Dalam ungkapan Gilster (2007), literasi digital dimaknai sebagai kemampuan membaca, memahami dan analisa berbagai sumber digital. Untuk itu, literasi digital perlu didorong sebagai mekanisme pembelajaran, yang terstruktur dalam kurikulum, atau setidaknya terkoneksi dengan sistem belajar-mengajar.

Belajar mandiri adalah belajar dengan motivasi dan terarah yang didorong oleh motif untuk menguasai suatu kompetensi dengan bekal pengetahuan kompetensi yang telah dimiliki peserta didik (Mujiman, 2011:1). Perbedaan kemnadirian belajar peserta didik dapat dilihat dari motivasi dan minat peserta didik dalam belajar. Peserta didik yang tidak memiliki motivasi dan minat dalam belajar tidak akan mampu belajar mandiri dan mengalami berbagai kesulitan dalam akademiknya. Peserta didik yang memiliki kemandirian belajar yang tinggi akan termotivasi untuk mempelajari sesuatu dengan kemampuannya tanpa meminta bantuan orang lain.

Mengingat proses belajar yang dilakukan di sekolah memiliki keterbatasan waktu, maka kemandirian belajar dipandang sebagai suatu hal yang mutlak harus dilakukan oleh peserta didik. Kemandirian belajar peserta didik ini perlu dikembangkan, ditingkatkan dan dibiasakan serta dilatih kepada setiap peserta didik oleh segenap pihak di sekolah, baik guru mata pelajaran, wali kelas dan termasuk pula guru bimbingan dan konseling. Pada kenyataannya menunjukan bahwa terdapat peserta didik yang belum memiliki kemandirian belajar yang baik. Hal itu tampak dari gejala-gejala yaitu: sering mencontek saat ulangan, disaat guru belum masuk kelas peserta didik- siswi asik bercanda gurau, asik mengobrol dengan teman saat guru menjelaskan, kurangnya inisiatif untuk bertanya jika ada materi yang belum dipahami. Atas dasar paparan latar belakang tersebut, penelitian ini dilakukan untuk mengkaji lebih dalam tentang kemandirian belajar.

Pembelajaran materi Pembelahan Sel selama ini masih dianggap sebagai pembelajaran yang sulit. Anggapan ini tercermin dari motivasi dan persepsi peserta didik yang sebagian besar merasa takut untuk tidak mampu menguasai materi Pembelahan Sel yang dipelajari. Pembelahan Sel merupakan materi pembelajaran yang kompleks karena dalam konsep ini mempelajari proses/mekanisme biologis yang abstrak dan rumit di dalam sel. Materi Pembelahan Sel sulit dipahami, karena dalam Pembelahan Sel terdiri atas tahapan-tahapan yang rumit, abstrak dan melibatkan banyak enzim yang susah untuk diingat fungsi masing-masingnya, yang memang sulit untuk bisa ditemukan atau dihadirkan secara nyata pada peserta didik. Untuk bisa memahami mekanisme fisiologis secara detil, diperlukan alat bantu berupa media yang tidak biasa. Gejala-gejalanya juga tidak bisa diamati secara langsung meskipun menggunakan alat laboratorium yang memadai sekalipun.

Upaya mengatasi keterbatasan pengamatan dan interaksi langsung peserta didik dengan obyek dan persoalan 
Pembelahan Sel itu dilakukan oleh sebagian besar guru dengan menggunakan media gambar, charta atau model. Pemanfaatan media gambar, charta atau model selama ini memang telah membantu guru membelajarkan peserta didik khususnya untuk masalah Pembelahan Sel, tetapi untuk persoalan mekanisme Pembelahan Sel media tersebut menjadi tidak optimal. Hal ini disebabkan karena tidak munculnya gejala visualisasi gerak (gejala peristiwa) yang menunjukkan proses atau mekanisme yang terjadi pada Pembelahan Sel pada media gambar atau charta tersebut. Akibatnya, peserta didik masih sulit untuk bisa menyerap dan memahami secara komprehensif mekanisme dan persoalan Pembelahan Sel. Dampak lebih lanjut yang kurang baik adalah munculnya persepsi pada diri peserta didik bahwa pelajaran tentang Pembelahan Sel merupakan pelajaran yang abstrak dan banyak hafalannya.

\section{Rumusan Masalah}

Berdasarkan latar belakang masalah diatas, maka rumusan masalah penelitian ini adalah "Bagaimanakah Pemanfaatan Bahan Ajar Biologi Berbasis Internet pada Pembelajaran Materi Pembelahan Sel dapat Meningkatkan Kualitas Pembelajaran, Pemahaman Konsep, Menumbuhkan Budaya Literasi Digital dan Kemandirian Belajar ?"

\section{Tujuan}

Penelitian ini bertujuan untuk mendeskripsikan bagaimana Pemanfaatan Bahan Ajar Biologi Berbasis Internet pada Pembelajaran Materi Pembelahan Sel dapat Meningkatkan Kualitas Pembelajaran, Pemahaman Konsep, Menumbuhkan Budaya Literasi Digital dan Kemandirian Belajar

\section{Manfaat Penelitian}

1. Melatih kemampuan peserta didik dalam memenfaatkan bahan ajar berbasis internet.

2. Menumbuhkan Budaya Litersi Digital pada peserta didik

3. Menumbuhkan karakter kemandirian belajar pada peserta didik

4. Memudahkan peserta didik untuk memahami konep-konsp biologi yang abstark menjadi lebih nyata karena visualisasi proses dan mekanisme dapat dihadirkan
5. Memberikan suasana belajar yang lebih bermakna, menyenangkan, efektif dan efisien

6. Dapat memberikan pengalaman baru dan memotivasi peserta didik dalam pembelajaran biologi

7. Memberikan variasi dalam penggunaan metode pembelajaran biologi

\section{METODE PENELITIAN}

Penelitian ini dilakukan di SMA Negeri 3 Rantau Utara, beralamat di Jln. WR. Supratman Rantauprapat, Kecamatan Rantau Utara, Kab. Labuhanbatu. Penelitian dilaksanakan mulai Oktober sampai Desember 2017.

Subyek Penelitian ini adalah kelas XII IPA 1 di SMA Negeri 3 Rantau Utara. Peserta didik di kelas ini berjumlah 36 orang peserta didik. Obyek penelitian adalah materi pembelahan sel. Variabel bebas penelitian ini adalah Pemanfaatan Bahan Ajar Biologi Berbasis Internet dalam Pembelajaran Materi Pembelahan Sel. Variabel terikat penelitian ini adalah pemahaman konsep, Budaya Literasi Digital dan Kemandirian Belajar

Penelitian ini menggunakan pedekatan deskriptif kualitatif. Menurut Bogdan dan Biklen dalam Moleong (2000:75) adalah prosedur penelitian yang menghasilkan data deskripsi berupa katakata tertulis atau lisan dari orang-orang dan perilaku yang dapat diamati. Penelitian ini digunakan empat jenis instrumen pengumpulan data yaitu: tes, angket, observasi, dan dokumentasi.

\section{PEMBAHASAN \\ Media Animasi Biologi di Internet}

Masalah terbatasnya media

pembelajaran khusunya untuk materi Pembelahan Sel di atas pada dasarnya dapat diatasi secara mudah dengan memanfaatkan media internet. Melalui internet kita bisa dengan mudah mencari dan mendapatkan informasi seputar perkembangan ilmu pengetahuan dan teknologi, termasuk informasi-informasi lain yang kita butuhkan. Informasi tentang ilmu pengetahuan dan teknologi tersebut disajikan dan disediakan internet dalam bentuk yang beragam. Khusus untuk ilmu biologi, saat ini banyak situs internet yang menyajikan informasi tentang materi-materi biologi yang dapat dimanfaatkan dalam pembelajaran, dalam bentuk media animasi yang inovatif. Media 
animasi biologi ini pada dasarnya dikembangkan dengan mengaplikasikan program animasi komputer seperti Macromedia Flash sehingga menghasilkan produk yang sangat menarik dan interaktif.

Upaya untuk memperjelas penjelasan guru salah satunya adalah dengan memvisualisasi materi pelajaran melalui berbagai media. Ariawati (2011) menerangkan bahwa dalam perkembangan teknologi multimedia, visualisasi merupakan salah satu cara yang dapat dilakukan untuk mengkongkritkan sesuatu yang abstrak. Saat ini multimedia telah menembus sistem pendidikan sebagai alat pembelajaran yang efektif. Komputer animasi dan simulasi saat ini merupakan alat yang penting untuk pendidikan sains. Salah satu contoh program pembelajaran dalam komputer yakni: macromedia flash. Media ini dapat membuat cara berpikir peserta didik lebih konkrit yang nantinya akan meningkatkan pemahaman materi yang diajarkan, karena macromedia flash merupakan salah satu program berupa tampilan pesan audio visual secara jelas kepada peserta didik dengan berbagai gambar animasi yang dapat merangsang minat belajar peserta didik.

Pada dasarnya, seorang guru dapat membuat media animasi pembelajarannya sendiri apabila ia memiliki keterampilan mengaplikasikan program animasi komputer tersebut. Hanya saja, untuk belajar dan menguasai keterampilan itu dibutuhkan waktu, tenaga dan biaya yang tidak sedikit yang tampaknya justru akan menambah berat beban guru. Oleh karenanya, ketersediaan media animasi biologi pada internet sepertinya dapat menjadi solusi yang baik untuk memecahkan masalah penyediaan media pembelajaran biologi. Kaitannya dengan masalah terbatasnya media pembelajaranuntuk materi struktur fungsi sel, media animasi biologi yang banyak dikembangkan dan disajikan beberapa situs internet saa ini tidak hanya mampu menampilkan gejala kebendaan Pembelahan Sel saja, tetapi sekaligus mampu menampilkan gejala peristiwa berupa proses atau mekanisme fungsi fisiologis selama proses Pembelahan Sel itu lewat animasi-animasi yang diciptakan. Dengan kata lain, gambaran lebih nyata tentang Pembelahan Sel dan proses fisiologis Pembelahan Sel dapat diamati dengan mudah lewat simplifikasi animasi tersebut. Inilah kelebihan yang dapat dipetik dari ketersediaan media animasi biologi di internet.

Contoh situs internet yang menyediakan media animasi biologi khususnya untuk materi Pembelahan Sel, di antaranya adalah https://lowphproductions.com/wa_files/06_M H_CellCycle.swf dan https://www.wiley.com/college/test/0471787 159/biology basics/animations/mitosis.swf

\section{Langkah-langkah Pemanfaatan Bahan Ajar Media Animasi Biologi}

Untuk dapat memanfaatkan media animasi yang ada pada internet, guru perlu mengembangkan bahan ajar berbasis media animasi dari internet yang sesuai dengan kebutuhannya. Upaya pengembangan bahan ajar materi Pembelahan Sel berbasis media animasi internet ini dapat dilakukan untuk mensiasati persoalan tidak tersedianya fasilitas internet bagi sekolah-sekolah. Artinya, guru tetap bisa mengembangkan strategi pembelajaran secara interaktif berbasis komputer dengan tetap memanfaatkan media animasi biologi dari internet. Selain itu, manfaat lain dari pengembangan bahan ajar ini adalah mengurangi risiko penyimpangan perilaku peserta didik jika mereka diminta mengakses sendiri media animasi biologi di luar sekolah, tetapi mereka tetap bisa belajar dengan media yang menyenangkan dan inovatif.

Pengembangan bahan ajar berbasis media animasi dari internet ini pada dasarnya mudah dan sederhana. Langkah-langkah yang harus dilakukan guru adalah:

1. Mencari situs-situs animasi Pembelahan Sel. Situs-situs yang menyediakan animasi Pembelahan Sel dapat dicari dan ditemukan melalui alamat situs yang sudah cukup terkenal, seperti Google. Caranya adalah:

a) Membuka situs Google.

b) Mengetik kata kunci untuk file animasi yang kita cari pada situs Google tersebut, dengan memberi tambahan kata filetype:swf, lalu tekan enter.

c) Setelah mesin pencarian terbuka, kita dapat membuka salah satu file yang ada pada situs tertentu sesuai dengan kebutuhan kita, dengan meng-klik kata atau frase yang bergaris bawah.

d) Setelah halaman muka situs animasi biologi yang kita butuhkan terbuka, berarti langkah mencari situs 
Vol. 5, SNo. 2 Desember 2018,

Hal. 40 - 48

animasibiologi telah berhasil kita lakukan.

2. Mengunduh dan menyimpan media animasi yang telah diperoleh. Tujuan langkah kedua ini adalah untuk mengambil dan menyimpan kembali tampilan media animasi biologi yang telah ditemukan ke dalam folder penyimpan

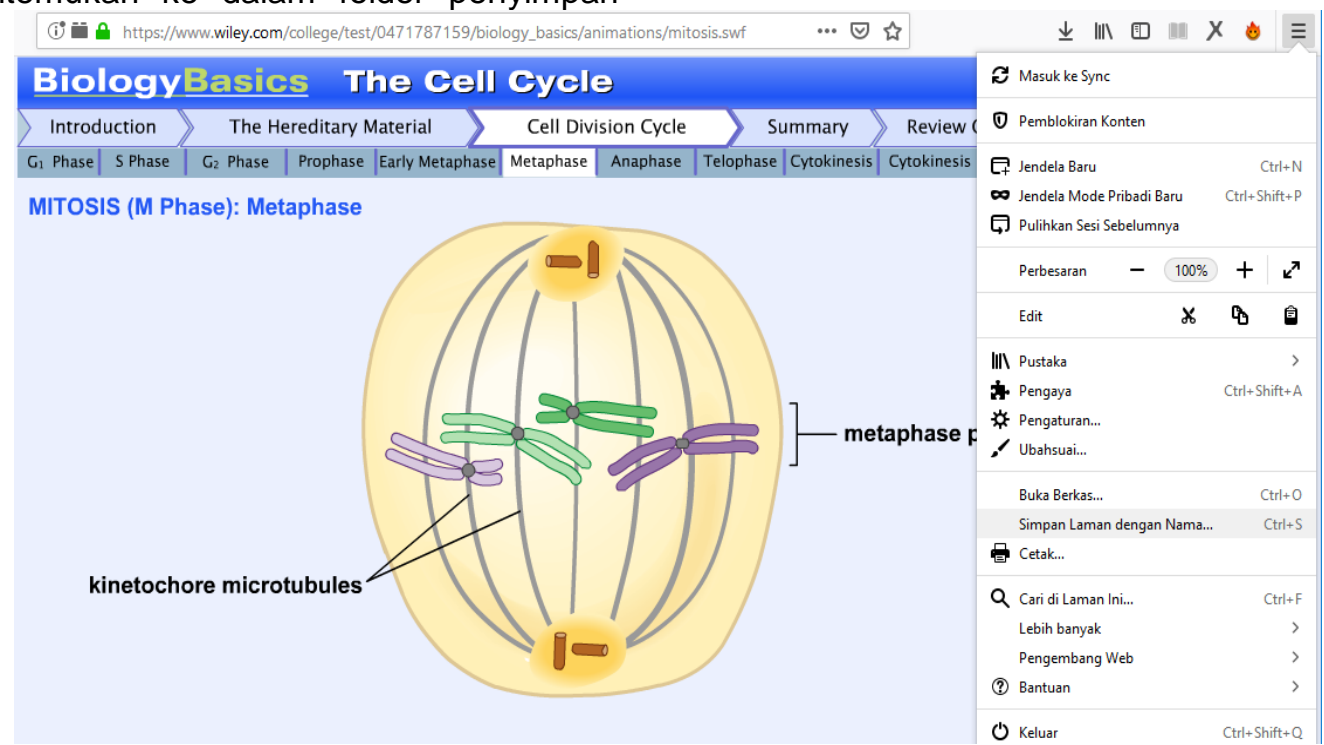

\section{Gambar 1: Save Page As (file.swf) dari situs https://www.wiley.com/college/test/0471787159/biology_basics/animations/mitosis.swf}

Kemudian ganti nama file sesuai keinginan kita. Pilih atau buat folder untuk menyimpan filenya, selanjutnya open, kemudian klik save. File akan tersimpan pada folder yang kita pilih. sendiri sehingga dapat dimanfaatkan kembali sewaktu-waktu tanpa harus mengakses situs sumber media tersebut. File animasi biologi tersebut kita unduh secara langsung, dengan mengklik toolbar buka menu, kemudian pilih simpan laman dengan nama...atau Save Page As

Kemudian ganti nama file sesuai keinginan kita. Pilih atau buat folder untuk menyimpan filenya, selanjutnya open, kemudian klik save. File akan tersimpan pada folder yang kita pilih.

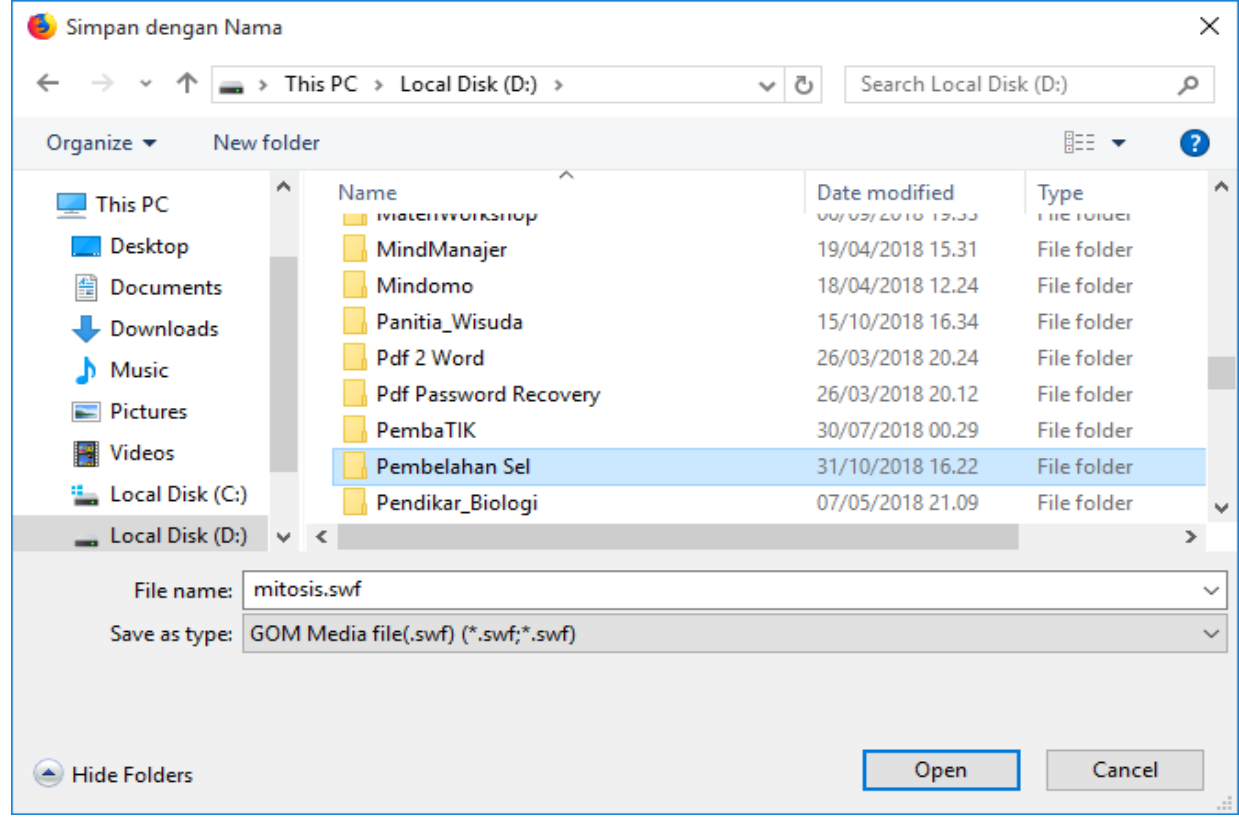

Gambar 2: Membuka atau membuat folder 
3. Membuat perangkat pembelajaran yang lain. Perangkat pembelajaran yang dimaksud adalah seperti Lembar Kegiatan Peserta Didik (LKPD) atau modul yang dibuat sesuai dengan media animasi yang telah didapat dan disimpan sebelumnya. LKPD yang disusun dapat digunakan untuk mengembangkan keterampilan mengamati, menganalisis dan mensintesis pengertian dari gejala yang telah diamati dan dianalisis. Gejala dan mekanisme proses Pembelahan Sel ini dapat diamati tata urutannya yang kemudian dianalisis gejala perubahanapa yang terjadi yang dari perubahan gejala tersebut peserta didik membuat strukturisasi, pengertian, mekanisme, proses atau konsepnya sendiri. Strukturisasi, pengertian, mekanisme, proses atau konsepnya ini lantas didiskusikan bersama dalam kelas dimana guru sebagai fasilitator. Pada saat diskusi ini peserta didik pun dapat mengembangkan keterampilan $4 \mathrm{C}$, literasi digital dan kemandirian belajar. Satu hal yang perlu diperhatikan lagi adalah bahwa perangkat komputer yang digunakan untuk pembelajaran dengan media animasi ini harus memiliki fasilitas multimedia, khususnya program Macromedia Flash, karena media animasi biologi yang digunakan hanya bisa dijalankan dengan program tersebut.

\section{Hasil Yang Dicapai}

Berdasarkan hasil analisa data dari pembahasan maka dapat disimpulkan bahwa Pemafaatan bahan ajar berbasis internet cukup efektif. Dari hasi tes penguasaan konsep diperoleh data nilai rata-rata 81,94, nilai tertinggi 90 , dengan ketuntasan kelasikal mencapai 80,55 \%. Sebanyak 79\% responden mengatakan bahwa pemanfaatan internet itu dapat membantu memberikan pemahaman yang lebih dalam terhadap materi yang sedang dibahas, sebab dapat menjelaskan konsep yang sulit atau rumit menjadi mudah lebih sederhana, sehingga itu dapat menambah motivasi peserta didik untuk terus belajar dan memanfaatkan internet sebagai media pembelajaran sehingga dapat meningkatkan pemahaman terhadap konep-konsep yang dipelajari.

\begin{tabular}{rc} 
Nilai rata-rata: & 81.94 \\
Nilai tertinggi: & 90 \\
Nilai terendah: & 62 \\
\hline Kan Klasikal (\%): & 80,55
\end{tabular}

\section{Tabel 1. Hasil Tes Penguasaan Konsep}

Budaya literasi digital tumbuh dengan baik, karena sebagian besar peserta didik sudah memiliki inisiatif di dalam mencari berbagai ilmu pengetahuan dari sumber internet, kemampuan membaca, memahami dan analisa berbagai sumber digital sudah meningkat.

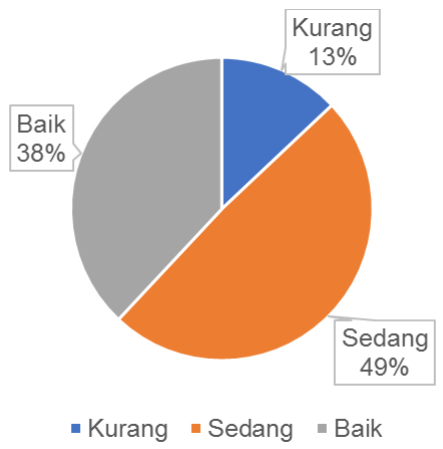

Gambar 3. Grafik Kemampuan membaca sumber digital 
Vol. 5, No. 2 Desember 2018,

Hal. $40-48$

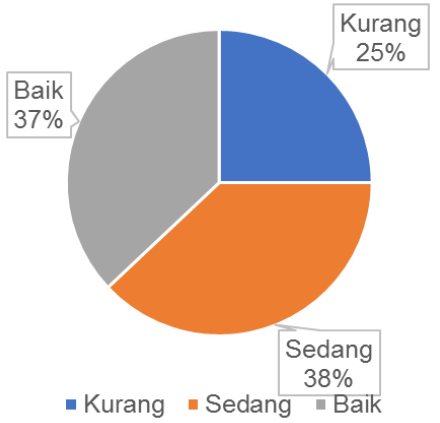

Gambar 4. Grafik Kemampuan memahami sumber digital



Gambar 5. Grafik Kemampuan menganalisis sumber digital

Dari sisi kemandirian belajar juga sudah terlihat meningkat. Hal itu tampak bahwa tingkat percaya diri, tanggungjawab dan disiplin peserta didik sudah baik. Disamping itu juga sudah tidak ditemui lagi peserta didik yang mencontek saat ulangan, disaat guru belum masuk kelas peserta didik sudah menyiapkan bahan ajar atau sumber belajarnya masingmasing, perhatian peserta didik sudah lebih fokus ketika guru memberikan klarifikasi atau penguatan, inisiatif untuk bertanya, memberi tanggapan, berdiskusi dan berinteraksi multiarah sudah meningkat.

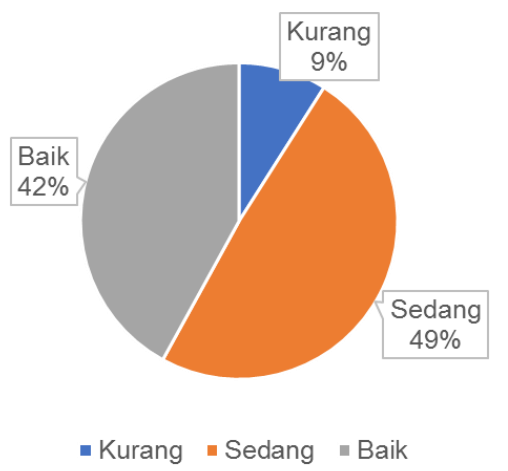

Gambar 6. Grafik Tingkat Percaya Diri peserta didik 
Vol. 5, No. 2 Desember 2018,

Hal. 40 - 48

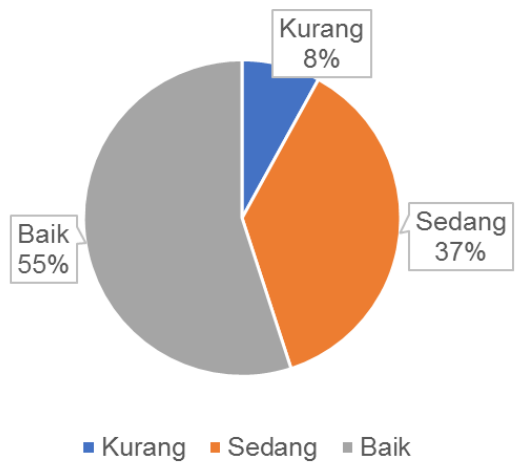

Gambar 7. Grafik Tingkat Tanggungjawab peserta didik

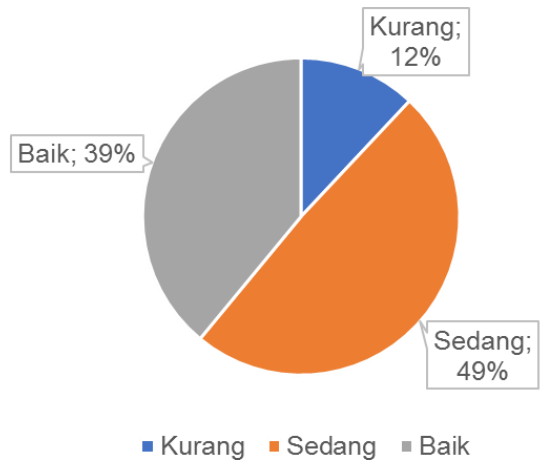

Gambar 8. Grafik Tingkat Disiplin peserta didik

\section{Hambatan}

Media-media animasi Pembelahan Sel yang ada pada internet pada dasarnya memang dapat diakses dengan sangat mudah. Tetapi, untuk dapat dimanfaatkan dalam proses pembelajaran, terdapat beberapa kendala yang sepertinya tidak mudah diatasi oleh guru atau sekolah, yaitu:

1. Masih banyak sekolah yang belum memiliki akses internet dengan baik, terutama sekolah-sekolah yang berada di daerah tertinggal, terdepan, dan terluar (3T).

2. Kekhawatiran orangtua saat anaknya mengakses internet adalah terpapar konten yang tidak pantas atau di-bully atau menjadi korban sebuah kejahatan cyber. apabila peserta didik diberi tugas untuk mengakses dan mencari media/situs animasi biologi secara mandiri di luar sekolah. Selain itu, risiko ekonomi berupa bertambahnya beban peserta didik untuk membayar jasa akses intenet dapat memicu masalah lain.

3. Sajian materi atau tampilan media animasi biologi yang ada pada intenet belum tentu selalu sesuai dengan apa yang dibutuhkan guru. Hal ini dapat memberi dampak pada rendahnya motivasi guru untuk berinovasi memanfaatkan media animasi itu, dalam arti hanya menggunakan langsung media animasi

biologi yang ada di internet tanpa menyesuaikan dengan kebutuhannya dan ini dapat memberi dampak pada tidak jelasnya proses pembelajaran yang akan dijalani peserta didik.

\section{KESIMPULAN}

1. Guru dapat memanfaatkan media animasi biologi dari internet untuk dikembangkan menjadi bahan ajar dengan melakukan:

a) mencari situs-situs animasi biologi,

b) mengunduh dan menyimpan media animasi yang telah diperoleh,

c) membuat perangkat pembelajaran lain seperti LKPD atau modul untuk melengkapi media animasi tersebut menjadi bahan ajar

2. Pemanfaatan bahan ajar Pembelahan Sel menggunakan media animasi berbasis internet ini memiliki kelebihan berupa munculnya gejala visualisasi gerak (gejala 
peristiwa) yang menunjukkan proses atau mekanisme yang terjadi pada pembelahan sel dengan simplifikasi animasi media tersebut, sehingga peserta didik dapat mengamati dan memperoleh gambaran nyata proses yang terjadi, tidak seperti media gambar, charta atau model.

3. Pemanfatan bahan ajar untuk pembelajaran Pembelahan Sel menggunakan media animasi berbasis internet dapat meningkatkan kualitas pembelajaran, pemahaman konsep Pembelahan Sel, menumbuhkan budaya litersi digital dan kemandirian belajar.

\section{SARAN}

1. Memperhatikan potensi internet dan dampaknya apabila dimanfaatkan secara terencana dalam kegiatan pembelajaran, para guru diharapkan dapat merencanakan pemanfaatan internet dalam kegiatan belajar-mengajar secara teratur sehingga peserta didik mendapatkan pengalaman belajar dari sumber belajar di luar guru yang berhubungan dengan materi pelajaran dan meningkatlkan kemampuan literasi digital peserta didik

2. Kepala Sekolah selaku pengelola sekolah diharapkan dapat memfasilitasi pemanfaatan media internet untuk pembelajaran

3. Perlu adanya penelitian lebih lanjut tentang efektivitas pemanfaatan media animasi berbasis internet yang dikembangkan menjadi bahan ajar ini dalam proses pembelajaran.

4. Diperlukan suatu program pelatihan untuk meningkatkan keterampilan guru-guru dalam memanfaatkan internet sebagai upaya mengembangkan media pembelajaran atau bahan ajarnya, khususnya dalam hal pemanfaatan media animasi berbasis internet.

\section{DAFTAR PUSTAKA}

Anonim. (2003). https://www.wiley.com/college /test/0471787159/biology_basics/anima tions/mitosis.swf (diakses pada 12 Oktober 2017).

Ariawati, R. 2011. Studi Komparasi Metode Pembelajaran TPS Think Pair Share Menggunaka Animasi Macromedia Flash dan Microsoft Power Point
Terdadap Prestasi Belajar Peserta didik Kelas X SMA Muhammadiyah 2 Surakarta Tahun Ajaran 2010/2011. (Diakses melalui: http://v2.eprints.ums.ac.id/archive/etd/1 3978/1/, tanggal 8 Agustus 2012)

Davis, C. H.; Shaw, D. (Eds.) (2011).Introduction to Information Science and Technology. Medford, NJ: Information Today, 2011.XII. 272 S. ISBN 978-1-57387-423-6

Gilster, P. (2007). Digital literacy, New York: Wiley

Moleong, Lexi J, (2005). Metodologi Penelitian Kualitatfi, Bandung : Remaja Rosda Karya.

Seta, A. K (2018) Literasi Digital Peserta didik harus https://republika.co.id/berita /pendidikan/eduaction/18/10/11/pgfa4v 335-kemendikbud-literasi-digitalpeserta didik-harus-diperkuat 